\title{
The solitude of the Orphan: Ğābir b. Ḥayyān and the Shiite heterodox milieu of the third/ninth-fourth/tenth centuries
}

\author{
Leonardo Capezzone* \\ Sapienza - University of Rome \\ leonardo.capezzone@uniroma1.it
}

\begin{abstract}
The community of Shiite alchemists gathered under the pen name of Ğābir b. Hayyān produced an important corpus first studied by Paul Kraus, who dated it between the third/ninth and fourth/tenth centuries. The religious, doctrinal and political issues of the corpus - especially in the last two collections - show that the Ğābireans were a real sectarian trend unknown to heresiographers. Kraus, along with some scholars after him, understood the Ğābirean community to be an expression of Ismaili thought. This paper aims to reconsider: a) the religious and political affiliation of Ğābir's alchemical community in the light of textual comparisons that show a close connection between the Gaäbireans and the esoteric tenets characterizing the Shiite $\dot{g} u l u w w$ as mirrored in the heresiographic sources of the late third/ninth and early fourth/tenth centuries, and in the Gulatt literary sources; and b) the last collection of the Ğābirean corpus as a polemical outcome specific to the Shiite milieu between the lesser and the greater Occultation of the twelfth Imam.

Keywords: Ğābir b. Hayyān, Early Shiite history, Islamic heresiography, Shiite heterodoxies, Politics and religion in Islamic middle ages
\end{abstract}

\section{Introduction}

The community of Shiite alchemists gathered under the pen name of Ğābir b. Hayyān ${ }^{1}$ produced an important corpus usually believed by scholarship to have been redacted between the third/ninth and fourth/tenth century. ${ }^{2}$ The corpus deals not only with alchemy but also - especially in the last two collections

* I wish to thank the anonymous readers for their relevant suggestions and remarks.

1 Henceforth references to Ğābir b. Hayyān will mean the plurality of the members of the Ğābirean community. My definition of the Ğābirean as a community strictly depends on the theoretical outline provided in T. Kuhn, The Structure of Scientific Revolutions (Chicago: Chicago University Press, 1970).

2 Cf. T. Delva, "The Abbasid activist Hayyān al- Atțār as the father of Jābir ibn Hayyān: an influential hypothesis revisited", Journal of Abbasid Studies 4, 2017, 35-61. As for other opinions on dating the Ğābirean corpus see D. de Smet, "Ja far-e Șādeq iv. Esoteric sciences", Encyclopaedia Iranica (EIr), XIV/4, 362-3. 
- religious, doctrinal, and political issues which led scholars to understand the Ğābirean community as a particular expression of the Shiite extremist milieu of that period.

The identity of the members, as well as the historicity of their activities, has always been protected by secrecy. Contemporary sources - with some important exceptions such as Ibn al-Nadīm - appear to have firmly shrouded the Ğābireans in silence, and they managed to escape completely the heresiographic view, as if they had no impact at all on the Shiite sectarian context which surrounded them. Secrecy and anonymity as social and literary devices of voluntary absence - or concealment - are not exclusive prerogatives of the alchemists' community. In general terms, they may be traced to a literary feature of the medieval Arabic culture whereby attributing a literary work to an author who has mastered the genre to which the work belongs represents a guarantee of authoritativeness and success. ${ }^{3}$ In this case, the founding narrative according to which the alchemical corpus would have been authored by Ğābir b. Hayyān, the pupil of the sixth Imam Ğa far al- Șādiq (d. 148/756), highlights both the powerful aspect of the Imam as a source of (salvific) knowledge, and Ğābir's existence as well as his writings dating back to the second/eighth century. ${ }^{4}$ However, as regards the intellectual motives underlying the Ğäbirean aim, the use of secrecy and anonymity is in many ways comparable to that of the tenth-century philosophicalscientific community known as Ihwän al-Șafă ${ }^{5}$

The founding contribution to the study of Ğābir b. Hayyān's corpus is the work of Paul Kraus. Between 1935 and 1945 he published a collection of Ğābirean texts, followed by a seminal essay on Ğābir and Greek science. ${ }^{6}$ Throughout his research Kraus highlighted the dependence of Arabic alchemical knowledge as reflected in Ğābir's corpus on the cultural traditions of late antiquity, so following a research paradigm which obscured the relationship between Ğābirean (and Arabic) alchemy and Chinese alchemy. ${ }^{7}$

The amount of data Kraus collected has revealed the existence of an alchemical school, established in the third/ninth century and developed during the fourth/tenth century, named after the alleged disciple of Ğa far al-Șādiq and placed under the authority of the sixth Shiite Imam. Hence, the Ğābirean corpus

3 A. Kilito, L'auteur et ses doubles. Essai sur la culture arabe classique (Paris: Éditions du Seuil, 1985).

4 Confusion over the early date of the Ğābirean corpus during the fourth/tenth century is recorded by Ibn al-Nadīm, Fihrist, ed. R. Tağaddud (Tehran: Marwī, 1391/1977), 420-1.

5 Y. Marquet, La philosophie des alchimistes et l'alchimie des philosophes: Jābir ibn Hayyān et les Frères de la Pureté (Paris: Maisonneuve et Larose, 1988), where a connection between the members of the two communities is assumed.

6 [ps.] Ğābir b. Hayyān, Muhtār Rasā'il, ed. Paul Kraus (Paris and Cairo: Maktaba al-Hुānğī, 1354/1936) (henceforth $M R$ ); P. Kraus, "Contribution à l'histoire des idées scientifiques dans l'Islam. I. Le Corpus des écrits jabiriens" (henceforth "Contribution I"), 43, 1944, 1-214; Kraus, "Contribution à l'histoire des idèes scientifique dans l'Islam. II. Jābir et la science grecque" (henceforth "Contribution II"), Mémoires présentés à l'Institut d'Égypte, 42, 1945, 1-406.

7 J. Needham, Science and Civilisation in China, vol. V, 4, China and the Arabic World (Cambridge: Cambridge University Press, 1980), 308-490, has demonstrated the increasing importance of organic alchemy, influenced by the Chinese alchemical culture, throughout the Ğābirean treatises. 
was a work in progress and the outcome of investigations carried out over approximately a century. The apparent internal cohesion, as well as crossreferences, suggests that it was constantly updated and rehashed to reflect continuity of thought, while remaining loyal to the rule - or method - of the voluntary dispersion of knowledge (tabdì al- $i l m){ }^{8}$

The chronology and internal organization of the corpus established by Kraus are based on Ibn al-Nadīm's source. As is well known, the bibliographer of Baghdad recorded that the Ğābirean treatises were gathered into four collections: the Hundred and Twelve Books; the Seventy Books; the Books of Balances; and the Five Hundred Books. The evolution of the corpus is more evident in the third and fourth collections: increasing importance is placed on the epistemological and theoretical aspect of the alchemical investigation, while treatises are devoted to religious, political and doctrinal issues close to the esoteric tenets characterizing the Shiite $\dot{g} u l u w w$ as mirrored in the heresiographic sources of the late third/ninth and early fourth/tenth centuries and in the few surviving Gulät literary sources produced in that period.

One Ğābirean treatise in particular - the Kitāb al-Raḥma - stands apart. Ibn al-Nadīm wrote that some sceptics of his time remained unconvinced that Ğābir had authored the whole corpus. They admittedly acknowledged that Kitāb al-Rahmma was the only treatise really authored by Ğābir b. Hayyān. Indeed, this text is not included in the list, and Ibn al-Nadīm only mentioned it in the biographical section. ${ }^{9}$ Kraus considered the manuscripts of the Kitāb al-Rahma as evidence of the continuous processing and rehashing of earlier materials, which was typical of the Ğābirean community. However, textual evidence led him to establish that the Kitāb al-Rahma preceded the corpus. His attitude towards this ancient work was curiously close to that of the sceptics mentioned by Ibn al-Nadīm; he actually deemed it separate from the whole Ğābirean corpus, and somehow extraneous to the issue of Ğābir b. Hayyān's historicity.

As for the community's belonging to the Shiite extremist wing, as reflected throughout the corpus in speculations about the figure of the Imam and the initiatory hierarchy of the epistemic access to his salvific knowledge, according to Kraus the Ğābireans' religious and political attitude may have been related to Ismailism or Qarmatism. The scholar's tragic death prevented him from developing such conjecture. ${ }^{10}$ The Ğäbirean connection with Ismaili doctrines has been discussed and accepted by scholars like Henri Corbin (to whom we shall return) and Yves Marquet, although this idea has been criticized in more recent research carried out by Pierre Lory. ${ }^{11}$

8 Cf. Kraus, "Contribution I", XXVII-XXX; P. Lory, Dix traités d'alchimie. Les dix premiers Traités du Livre des Soixante-dix (Paris: Sindbad, 1983), 242-4.

9 Ibn al-Nadìm, Fihrist, p. 420. The treatise is published in M. Berthelot and O. Houdas, La Chimie au moyen age, III, L'alchimie arabe (Paris: Imprimerie nationale, 1893), 13260 (French translation pp. 163-90); Kraus, "Contribution I", 5-9.

10 Kraus, "Contribution I", pp. XLVIII-LVII. P. Lory, Alchimie et mystique en terre d'Islam (Lagrasse: Verdier, 1989), 155-62, collected and translated from German with some notes from Kraus' archive, where data were gathered on the hypothesis of an Ismaili/Qarmati affiliation.

11 Some terms of the question are reported by M. Brett, "The Mīm, the 'Ayn, and the making of Ismā 'ilism”, BSOAS 57/1, 1994, 25-37. Marquet, La philosophie des alchimistes, 
Although the corpus shares cultural paradigms common to the Arabic Hermetic culture (which also imbued Ismaili natural philosophy) on which Kevin van Bladel shed new light, ${ }^{12}$ scholarship has usually perceived and consequently depicted the Ğābirean community as if it were separate, or even entirely absent, from the religious and political debates and tensions that dramatically animated the Shiite scene between the end of the third/ninth and first decades of the fourth/tenth centuries - the critical period between the lesser and the greater Occultation of the twelfth Imam. Thus, the Gäbireans and their corpus seem to be worlds apart in the historical space: although some of the later treatises of the corpus have a firmly politico-religious aim, which could suggest the Ğābireans were a real sectarian trend, coeval heresiography does not seem to have recognized their actual existence. The dating of the corpus has always been evaluated in relation to external elements and factors, while no attempt has been made to contextualize the activities of the Ğābirean community within the history of early Shiism.

On the contrary, this paper focuses on the presence of this alchemical community in the complex Shiite context of the fourth/tenth century, marked by the concealment of the twelfth Imam. In that period, a conflict between orthodox and heterodox doctrinal visions began to develop. The latter represented the expression of an élite, and hence advocated the superiority of the hermeneutic and esoteric interpretation of the charismatic knowledge of the Imam, to which scholars of early Shiism have turned their attention in recent years. ${ }^{13}$ In this context the sectarian milieu of the $\dot{g} u l u w w$ is described by the heresiography of the end of the third/ninth and beginning of the fourth/tenth century

p. 132, sees a possible Qarmati-Ismaili influence; see also Y. Marquet, "Á propos de la secte des auteurs jābiriens", Studia Islamica 73, 1991, 127-35. Lory, Alchimie et mystique, pp. 155-62, expresses doubts about those views, and leans towards an ultra-Shiite understanding of the politico-religious convictions of the Ğäbirean community.

12 K. Van Bladel, The Arabic Hermes (Oxford: Oxford University Press, 2009).

13 The conflict between normative and esoteric expressions of Shiism in the first centuries has been studied from different points of view: H. Halm, Die islamische Gnosis. Die extreme Schia und die 'Alawiten (Zurich: Artemis, 1982); M.A. Amir-Moezzi, Le guide divin dans le shi isme originel (Lagrasse: Verdier, 1992); M.A. Amir-Moezzi, The Silent Qur'an and the Speaking Qur'an. Scriptural Sources of Islam between History and Fervor (translated by Eric Ormsby, New York, Columbia Univ. Press, 2016, especially pp. 97-115); H. Modarressi, Crisis and Consolidation in the Formative Period of Shî ite Islam (Princeton: The Darwin Press, 1993): on gulāt and mufawwida 21-9; on the spread of mufawwida literature 33-6; on the period of the lesser gayba 59-105. A.A. Sachedina, Islamic Messianism: The Idea of Mahdi in Twelver Shi' ism (Albany: SUNY Press, 1981); A.J. Newman, The Formative Period of Twelver Shì ism (Richmond: Curzon, 2000). Moreover, studies dedicated to the birth and development of Nuṣayri doctrines, especially focused on al-Hașīi ì and his circle, complete the understanding of the gulāt presence within the Shiite landscape of the third/ninth-fourth/tenth centuries: M.M. Bar Asher and A. Kofsky, The Nusayrī-'Alawī Religion. An Enquiry into Its Theology and Liturgy (Leiden: Brill, 2006); Y. Friedman, The Nusayri-'Alawiss: An Introduction to the Religion, History and Identity of the Leading Minority in Syria (Leiden: Brill, 2010). 
(ps. al-Nāši ' al-Akbar, al-Nawbahtī, al-Qummī) $){ }^{14}$ with various doctrinal fronts claiming the intellectual (and political) legacy of the vanished Imam and its correct interpretation. A line of esoteric thought can be recognized among these various fronts. Shiite Imamite heresiography of the fourth/tenth-fifth/eleventh centuries traces this line back to some of the most intimate disciples of Ğa far al-Ṣādiq (such as Abū'l-Hatțāb and Mufaḍdal ibn 'Umar al-Ğu'fĩ). ${ }^{15}$ This same line is more evident in texts such as Umm al-Kitāb (UK), Kitāb al-Haft wa'l-azilla (KHA) and Kitāb al-Ṣirāt (KȘ) (all written between the third/ ninth-fourth/tenth and fifth/eleventh centuries). These texts emanate from an exegetical climate centred on the soteriological knowledge of the Imam which even permeates the doctrinal treatises of the Gābirean corpus: a common paraphrase reflecting an identical and shared religious and speculative disposition can be obtained by epitomizing the former and latter series of texts.

I shall seek to highlight some features of what can be defined as a Shiite style of thought, common to the surviving esoteric texts and the last production of the Ğābirean community, which early heresiography has long been concerned with. The first common feature is a historical issue that marked the origins of Shiite guluww: the transfer of the Alid Imam's charisma to people who had no genealogical ties with the Prophet Muhammad's family. Heresiographers understood that issue as a link between the early appearance of heterodoxy (e.g. the extremism professed by Abū'l-Hattāab) and the spread of doctrines such as those of the mufawwida or muhammisa sects in the third/ninth and fourth/tenth centuries. ${ }^{16}$ The convergence of the manifold meanings of this theme into the symbolism of a particular figure, the Orphan (yatim), can be observed over time.

\section{The Shiite $\dot{g} u l u w w$ and the transfer of the Imam's charisma outside the Alid genealogy}

The spread of religious propaganda centred on a non-genealogical, spiritual transmission of the imamate occurred with the revolt of 'Abd Allāh b. $\mathrm{Mu}$ 'āwiya, which broke out in $126 / 744$. While not a fully-fledged doctrine, it was based on the transfer of the Imam's religious charisma to an element outside of the Prophet's family, and was therefore extraneous to the genealogical link that gave rise to the conception of the passage of the Imamate and of politicalreligious charisma itself. The earliest heresiography provides a narrative of the spread of a set of beliefs relating to the heresy of 'Abd Allāh b. Harb. ${ }^{17}$

14 In general, on Imami Shiite heresiography see J. Van Ess, Der Eine und das Andere. Beobachtungen an islamischen häresiographischen Texten (Berlin: de Gruyter, 2011), I, 206-79.

15 al-Nağāšî, Kitāb al-Riğāl, ed. M.J. al-Nā'in̄̄ (Beirut: Dār al-aḍ̂ā', 1408/1988), II, 359-61.

16 Modarresi, Crisis and Consolidation, 21-8; W. Madelung, "Mukhammisa", Encyclopaedia of Islam (EI) 2, VII, 517-8; M. Asatryan, "Moknammesa", EIr online: http://www.iranicaonline.org/articles/mokammesa-sect.

17 (Ps.) al-Nāši' al-Akbar, Ușūl al-nihal, in J. Van Ess, Frühe mu'tazilitische Häresiographie: zwei Werke des Nāšì al-Akbar (gest. 293 H.) (Beirut and Wiesbaden: Steiner, 1971), 36-40; al-Qummī, Kitāb al-Maqālāt wa-l-firaq, ed. M.J. Maškūr (Tehran: Mu'assasat-i Maṭū' ātī 'Ațầ'̄, 1963), 39-43; al-Nawbahtī, Firaq 
According to the heresiographers, those beliefs would have been divulged by close disciples of Ğa far al-Ṣādiq. ${ }^{18}$ The main themes of these descriptions are: Messianism, the belief in the pre-existence of the souls of the Imams in the form of shadow (azilla); the antinomian exegetical tendency according to which knowledge of the word of the Imam frees people from the burden of the Law; and a gnosis founded on the ascent or descent of the soul which approaches or moves away from the saving knowledge of the Imam and experiences a path of transmutation (tanāsuh) through mineral, vegetable, and animal forms. The esoteric texts that appear to stem from the dissemination of these doctrines are the $U K, K H A$, and $K S .^{19}$

Tanāsuh seems to be the keyword indicating a heterodox style of thought that unifies the sectarian phenomena of $\dot{g} u l u w w$ described by the heresiographers. ${ }^{20}$ A comparison of the surviving texts emanating from the esoteric context linked to the transmission of the most intimate disciples of Ğa far al-Șādiq, the accounts of the heresiographers, and the Ğābirean treatises that deviate from alchemical concerns and instead show a more markedly doctrinal approach, allow us to construct a common paraphrase, taken from the same religious and epistemological horizon. This case may represent a process of intertextuality.

The term tanāsuh hints at this intertextuality. This word does not occur in the Kitāb al-Rahma, the earliest treatise attributed to the Ğäbireans, despite the fact that the text deals with the problem of the transmutation of bodies when they are

$a l-$ š̆ $^{\circ} a$, ed. H. Ritter (Istanbul: Staatsdruckerei, 1931), 29-35. On the myth of saba'iyya as a heresiographic pattern: W. al-Qadi, "The development of the term Ghulāt in Muslim literature with special reference to the Kaysāniyya", in A. Dietrich (ed.), Akten des VII. Kongresses für Arabistik und Islamwissenschaft (Göttingen: Vandenhoeck und Ruprecht, 1976), 295-319; S. Anthony, The Caliph and the Heretic: Ibn Saba' and the Origins of Shĩ ism (Leiden: Brill, 2012), 243-4, 309-10. On harbiyya, see P. Crone, The Nativist Prophets of Early Islamic Iran (Cambridge: Cambridge University Press, 2012), 92-5.

18 They are Ğābir b. 'Abd Allāh al-Anșārī and Ǧābir b. Yazīd al-Ǧu 'fĩ: al-Qummī, Maqālāt, p. 43; al-Nawbahtī, Firaq al-š̄i $a$, p. 31. Cf. L. Capezzone, "Pre-existence and shadows: a gnostic motif, or a literary one?" in I. Hassan (ed.), La littérature aux marges du 'adab. Regards croisés sur la prose arabe classique (Lyon and Beirut: Diacritique Éditions Presses de 1'Institut Français du Proche Orient, 2017), 336-56.

$19 U m m$ al-Kitāa $b=U K$, ed. W. Ivanow, Der Islam 23, 1936, 1-132; Kitab al-Haft wa-l-azilla $=K H A$, ed. 'Ā. Tāmir, I. 'A. Ȟālifa (Beirut: Imprimerie Catholique, 1970). Kitāb al-Sirāt $=K S$, in L. Capezzone, "Il Kitāb al-Sirāt attribuito a Mufaḍdal b. 'Umar al-Ju' fí. Edizione del ms. unico (Paris: Bibliothèque nationale ar. 1449/3) e studio introduttivo", Rivista degli Studi Orientali, 69, 1995, 295-416; S. Anthony, "The legend of 'Abdallāh ibn Sabā' and the date of Umm al-Kitāb", Journal of the Royal Asiatic Society, 21/1, 2011, 1-30; E.F. Tidjens, "Der mythologisch-gnostiche Hintergrund des Umm al-Kitāb", Acta Iranica 7, 1977, 241-526. H. Halm, "Das 'Buch der Schatten': Die Mufaddal-Tradition der Ghulat und die Ursprünge des Nusairiertum. I", Der Islam, 55, 1978, 219-66 (henceforth: "Das 'Buch der Schatten' I"); Halm, "Das 'Buch der Schatten': Die Mufaḍdal-Tradition der Ghulat und die Ursprünge des Nusairiertum. II" (henceforth: "Das 'Buch der Schatten' II"), Der Islam, 58, 1981, 15-86; Halm, Die islamische Gnosis, 113-99, 240-74; 128-61; M. Asatryan, Controversies in Formative Shi $i$ Islam: The Ghulat Muslims and Their Beliefs (London and New York: I.B.Tauris / The Institute of Ismaili Studies, 2017).

20 Cf. Amir-Moezzi, Le guide divin, 313-5. 
subject to certain alchemical operations. ${ }^{21}$ The aforementioned heresiographic texts seem to recognize it as the keyword of doctrines developed by the extreme sectarianism that stirred up the political and religious panorama between the second/eighth and fourth/tenth centuries - the period in which the Ğābirean corpus was redacted. However, when the heresiography quotes heterodox statements, issues concerning state transitions and transmutations of the soul frequently revolve around the verb intaqala and the verbal nouns of the root N-Q-L: precisely in the sense in which they occur in Gābir. On the other hand, textual findings regarding the term tanāsuh are highly recurrent in the $K H A$ and $K S$, which heresiographers may have used as sources. ${ }^{22}$ Indeed, in those texts the term tanāsuh always occurs within a semantic field that places it not only in inferential but also synonymical relationship with the term tarkī (structure, compound). Moreover, in a passage from the Ğābirean Kitab al-Hağar the author speaks of "some of our books (kutubunā) on tanāsuh". ${ }^{23}$ None of these texts survive today. However, the Persian alchemist al-Tugrā' (d. 514/1121) recorded a long fragment from a Kitāb al-Ištimāl repeatedly cited in the Ğābirean corpus. ${ }^{24}$ The main themes of this fragment are: time, the periodic cycles that mark the history of humanity, and the laws of the transmigration of souls. According to Ğābir, souls have a celestial origin, but they have lapsed and fallen into a state of admixture (with matter) (al-mizzăg - a widespread concept in the $K H A$ and $K S T$ ) that involves the world of generation and corruption. The author does not explain the causes of the fall, but frames them within the law of necessity. Fallen souls have to take on a number of forms to purify themselves from corruption and ignorance. ${ }^{25}$ The outcomes of this process of transmigration (mash and rash - other very frequent terms in the $K H A$ and $K S$ ) depend on the soul's insistence on error and sin, or on its choice to emancipate itself from ignorance. Ğābir lingers on the second alternative, which allows the soul to reacquire its original form along an ascending path marked by transmutations (intiqāl, takrīr) capable of purifying the structure of the body.

In the incipit to his version of the Ğābirean text, al-Ṭugrā' $\overline{1}$ thus writes: ${ }^{26}$

This text is interwoven with difficult metaphors (rumüz), because in the literal sense it is written in the language of the supporters of the transmigration of souls (mubannā 'alā kalām ahl al-tanāsuh fì-l-ẓāhir). In a

21 Technical data on the early date of the Kitāb al-Rahma are found in Kraus, "Contribution I", 5-9; Needham, Science and Civilisation in China, vol. V, 4, 435.

22 If al-Qummī, Maqālät, p. 42, can reproduce a fragment of the heterodox speech on the progression of knowledge intended as refinement and purification, placing it in alchemical similitude with a purification process, it is very likely that this also depends on a process of intertextuality in progress.

23 Kitāb al-Hağar, in The Arabic Works of Jābir ibn Hayyān (henceforth AW), ed. E.J. Holmyard (Paris: Geuthner, 1928), 15-42: 17.

24 Kitāb al-Ištimāl, in $M R, 548-55$. For its mentions throughout the Ğābirean corpus, see Kraus, "Contribution I", 165.

25 Cf. also Kitāb al-Hawāṣs $(M R, 378)$ and Kitāb Ustuqus al-uss al-țānī $(A W, 100)$. Both treatises belong to the collection of the Hundred and Twelve Books, which is earlier than that of the Book of the Balances and includes (according to the Ğābireans) the Kitāa al-Ištimāl.

26 Kitāb al-Ištimāl, in $M R, 548$. 
figurative sense, however, [it alludes] to the teaching of the [alchemical] Art. Indeed, I have the doubt that many readers will be misled by this book, will not understand its enigmas (mag்zāhu) and will dissolve them in the light of their outward sense.

Is tanāsuh a metaphor? ${ }^{27}$ The $K H A$ and $K S$ seem to use this term in the exegesis of some Quranic verses, adopting it according to the descriptive model it provides: a similitude between the processes of physical transformation and the evolutionary cycles of the soul. Knowledge of the Imam is salvific: the $K H A$ and $K S$ repeatedly state that the sin of ignorance, punished with the gradations of the tanāsuh, can only be healed by recognizing the Imam. Through the assumption of his redemptive knowledge, human beings can rediscover their original integrity. In his Kitāb al-Mulk, Gāair declares the correspondence between the supreme elixir, which allows the transmutation of base metals into silver and gold, and the Imam. They share the power to purify, reconstitute, and heal the soul from its malaise: 28

Know, o brother, that the water, when it is thoroughly mixed with the Tincture and the Oil, coagulates, fixing itself in a look similar to a coral grain. When it has reached this step, and has become a docilely and fusible matter which cerifies, by now able to penetrate all metals, well, if it is really like that, it is the Imam. [...] For God, for my teacher - God preserve him! I never revealed [this procedure] in any of my books, except in one, called Kitāb al-Mawāzinn. There I had spoken in such a way that no one could understand or sense the meaning. Those who had come to do this through their direct experience could not fully understand its meaning, except for one word. It may be that whoever came to the material achievement of the Work understood me. My word is: unless God grants you the joy of seeing the Imam. Who has never performed the operation will never understand what I am talking about. But I said this - for my teacher Ğa far al-Sāadiq, peace be upon him - in a clear and eloquent way, without symbols or enigmas, nor metaphorical expressions, as scholars usually do, and as I myself did in my books. I have done this so that my teacher - on him be peace - knows that I was neither ungenerous nor enigmatic in my words. Perhaps thanks to my effort, he will free me from the corruption of this world.

Therefore, in its metaphorical constructs Ğābirean speech recognized that the risk of an interpretative drift was to be avoided. The gap between Ğābir's utterance and al-Ṭugrā' $\overline{1}$ 's reading is at the very least disconcerting. When Ğābir adopts a metaphor he follows a stylistic code that produces clarity and rejects the enigma, which may be understood by those who share the same images

27 Cf. T. Kuhn, "Metaphor in science", and R. Boyd, "Metaphor and theory change: what is 'metaphor' a metaphor for?", both in A. Ortony (ed.), Metaphor and Thought (Cambridge: Cambridge University Press, 1979), respectively pp. 409-19 and 481-532.

28 Kitāb al-Mulk, in Berthelot-Houdas, La Chimie au Moyen Âge, III, 94-5. On the relationship between Imam and elixir cf. Lory, Alchimie et mystique, $59 \mathrm{ff}$. 
of knowledge. ${ }^{29}$ Thus, a process of intertextuality occurs in both the Ğābirean texts and the esoteric texts, which allows at least a unified paraphrase - which even those who remain outside the stylistic and epistemic code (the medieval heresiographer and the modern reader) could achieve. When al-Qummì, in his Kitāb al-Maqālāt, reports the terms of a cognitive progression toward the Imam, marked by the passing of tests, he may have had before him the Kitāb al-Ištimāl as well as some passages of the $K S$ or $K H A:^{30}$

Some of them do not believe that these verses [of the Quran] have a meaning of dispensation. Indeed, they believe that to every precept corresponds a sanction, and that the ultimate goal [of a discipline] is the passing of a test (imtihān). When a believer passes [the test], he can be considered free from the burden of impositions (saqațat 'anhu al-mihna). Therefore, it is not enough that the faithful be proficient and in a state of ritual purity, if he does not learn in depth the principles of the doctrine, because he will not pass his trial, and his knowledge will not experience progress in wisdom (lam yuhsin fíl-hikma ihtibāruhu). Just as pure gold, though purified through an acidic substance (hall) and fire [may still contain] some slag, so the faithful examined by his lord may still reveal impurities and concretions. This is why the faithful experiences and investigates (yahtabiru wa-yaftišu), and when he really gets cleansed and perfected, he can consider himself free from the prohibitions that bind others.

In the $K S$ we read: ${ }^{31}$

When the believer has reached the seventh step and with it he will have achieved its path, then it will emancipate itself from the bond of the adoration. He will be free, and emancipated (șāra hurran wa-muharraran). $\mathrm{He}$ can do without discipline ( $f a-s t a \dot{g} n \bar{a}$ ' alā al-ta' lìm) since he knows what is given to know, sees what is given to see, and hears what is given to hear. He will find what he aspired to, and finally he will be free from the burden of the quest.

Similarly, the same epistemic framework can be grasped by drawing a parallel between the initiatory hierarchy established in the $K S$ and that resulting from the Kitāb al-Hamsinn, at the top of which Ğābir places the Prophet, the Imam, and then the yatim, the Orphan, followed by the rank of the Threshold $(b \bar{a} b){ }^{32}$

29 I take the notion of images of knowledge (connected with that of body of knowledge) from Y. Elkana, Anthropologie der Erkenntnis (Frankfurt am Main: Suhrkamp, 1986).

30 al-Qummī, Maqālāt, 42.

$31 K S, 327$; but see the entire passage at 324-30. Cf. H. Halm, "Courants et mouvements antinomistes dans l'islam medieval", in G. Makdisi, D. Sourdel and J. Sourdel-Thomine (eds), La notion de liberté au Moyen Âge. Islam, Byzance, Occident (Pennsylvania and Paris: Dumbarton Oaks Colloquia IV (12-15 October 1982), 1985), 135-41: 138.

32 Kitāb al-Hamsīn, in MR, 489-500; cf. P. Kraus, "Les dignitaires de la hiérarchie religieuse selon Ğābir ibn Hayyān", in Bulletin de l'Institut Français d'Archéologie Orientale 41, 1942, 83-97. 


\section{The principle of the Orphan}

The transfer of charisma outside of the Prophet's family places particular emphasis on the Orphan. The role and rank of the Orphan (yatim) are magnified in the $U K$, the $K H A$, and the $K S$, making it one of the key figures of the initiatory hierarchy of proximity to the Imam's redemptive knowledge. One of the later treatises of the Ğäbirean community - the Kitāb al-Māğid contained in the last collection of the corpus, the Five Hundred Books - is devoted to the precedence of the three 'Ayn-Mìm-Sin principles ('Alī-Muhammad-Salmān) and the subordination of the principle of $\operatorname{Sin}$ to that of 'Ayn.

Henry Corbin based his approach to the Kitāb al-Mãğid on Kraus' hypothesis about the Ğābirean community's affiliation to Ismailism. The three doctrinal principles of 'Ayn, Mìm, and Sin were thus interpreted by Corbin's hermeneutic sensitivity in light of an Ismaili-oriented reading. ${ }^{33}$ However, Heinz Halm has shown that this nucleus of doctrines revolving around the supremacy of Muhammad, 'Alī and Salmān (of which, as we shall see, the Kitāb al-Māğid gives an exposition that implicitly re-emerges in the heresiography) was unknown in the context in which Fatimid Ismailite propaganda spread between the third/ninth and the fourth/tenth centuries. ${ }^{34}$

Let us return to some sources that describe the Shiite heterodox landscape in Baghdad during the fourth/tenth century. One of them is Mas 'ūdī. In one passage of his Murǚ̆ al-dahab the doctrines of the tanāsuh and the tafwìd (i.e. "entrustment", an echo of the emanationist doctrines, with which God entrusted the creation to the five members of the Prophet's family) are attributed to sectarian groups who believe that members of the Prophet's family pre-existed in shadow form (azilla). Two of these sects are of interest to us: muhammadiyya and 'ilbāniyya ('ilbā' '̄yya): ${ }^{35}$

This error was supported by many of their authors, and also by the most subtle of their theologians, who belonged to the muhammadiyya, 'ilbanniyya or even to other sects. Among these, we should remember Ishaq $b$. Muhammad al-Naha' $\overline{1}$, called al-Ahmar, well-known for his book entitled Kitāb al-Sirāt. This book has been refuted by al-Fayyāḍ b. 'Alī b. Muḥammad in his book entitled al-Qusțās, and by al-Nahkīnī. Those authors belong to the muhammadiyya, and have refuted the tenets of [the sect of the] 'ilbāniyya, which are professed in the Kitäb al-Sirāt. ${ }^{36}$ We have already had [elsewhere] the opportunity to talk about muhammadiyya, 'ilbāniyya, mugìiriyya and all the other heterodox doctrines, such as those of the entrustment (tafwi d), or the mediation

33 H. Corbin, "Le 'Livre du Glorieux' de Jâbir b. Hayyân”, in Eranos Jahrbuch 18, 1950, 47-114.

34 H. Halm, Kosmologie und Heilslehre des frühen Ismā ìliyya (Wiesbaden: Steiner, 1978), 142-68; cf. Brett, "The 'Ayn, the Mìm".

35 al-Mas' ūdī, Murū ̌̆ al-dahab, ed. Ch. Barbier de Meynard and A. Pavet de Courteille (Paris: Imprimerie Imperiale, 1861-77), III, 262-8.

36 The text mentioned by al-Mas 'ūdī is not the same $K S$ we are concerned with here: see M. Asatryan, Controversies, 97, 105. 
(wașa $\left.\bar{a}^{\prime} i t\right)$; we have already refuted them all and also the ones who preach the transmigration of souls (tanāsuh al-arwāh) in animal species, whether they are Muslims or wise men from ancient Greece, or India, or they are dualist, Zoroastrians, or Christians. We already gave our arguments against the heretics who have preceded us or who live in our time, in the year 322 [933-4].

To better understand this doctrinal framework it is useful to take a step forward to al-Šahrastānī: ${ }^{37}$

The 'Albā'iyya are the followers of al-'Albā' b. Dira' al-Dawsī, who set 'Alī above the Prophet, saying that Muhammad had been sent by 'Alī, whom he called a divine being [...]. Some believe in the divinity of both 'Alī and Muhammad, but for them 'Alī is superior; these are called the 'Ayniyya. Others who consider them both divine put Muhammad first; these are called the Mimiyya. Some others believe in the divinity of all five Companions of the Cloak: Muhammad, 'Alī, Fāțima, Hasan and Ḥusayn, all of them equally imbued with the spirit of God.

Al-Mas ' $\bar{u} \mathrm{~d} \overline{\mathrm{l}}$ describes, during a period of crisis brought about by the concealment of the twelfth Imam, some Shiite orientations speculating on a gnosis focused on the pre-existence of members of the Prophet's family, and their demiurgic function. The scenario seems to be split between muhammadiyya - or mìmiyya, as specified by al-Šahrastānī - which favours the absolute superiority of Muhammad's prophecy, and 'ilbāniyyal'albāniyya, ${ }^{38}$ or 'ayniyya, which instead exalts the role of 'Alī and believes in the pre-eminence of the wilaya over the nubuwwa, the interpreter of the Law over the legislator and the heir of the prophecy over the prophet himself. The surviving esoteric texts - especially the $K S$ - are unequivocally aligned on the principle of 'Ayn, and formulate with unusual clarity (which perhaps testifies their early dating) the terms of the theological framework on which this priority is based: the dependence of $i s m=$ Name $/$ Signifier $=$ Mim $=$ Muhammad upon $m a^{\prime} n \bar{a}=$ Sign $/$ Signified $=$ 'Al $\overline{1} .{ }^{39}$

The heresiographic texts make no mention of a third paradigm, that of the Threshold $(b \bar{a} b)$ which permits access to the Word and its Meaning. In the $U K$, the earliest of the texts containing the (alleged) ${ }^{40}$ teaching of the fifth and sixth Imams Muhammad al-Bāqir and Ğa far al-Șādiq, the emergence of this paradigm is clearly evident and centres around Salmān. Indeed, al-Qummī proves he is aware of the existence of doctrines revolving around the theme

37 al-Šahrastān̄̄, Kitāb al-Milal wa-l-niḥal, ed. W. Cureton (London: Society for the Publication of Oriental Texts, 1864), I, 134.

38 Cf. al-Qummī, Maqālāt, 59; 'Alyā'iyya according to Halm, Kosmologie und Heilslehre, $157-61$.

$39 K S, 378-83$.

40 On the historicity of the second-third/eighth-ninth century gilāt texts: T. Bayhom Daou, "The second-century Š̀i ite Gulāt: were they really gnostic?", Journal of Arabic and Islamic Studies 5, 2003-04, 13-60: 19 ff. 
of spiritual adoption. In the long paragraph dedicated to the sect named muhammisa, he writes: ${ }^{41}$

They believe that [...] God Almighty manifested himself to his creatures throughout all cycles and periods; he made himself visible to them in the form of light and urged them to accept the message of his unicity, but they refused. He became visible through the threshold of the prophecy ( $\min b \bar{a} b$ al-nubuwwa wa-l-risāla) but the creatures still refused. He then became visible through the threshold of the Imamate (min bāb al-imāma), and they accepted. Then God Almighty granted the Imamate and destined those who shared the pure substance of Muhammad to be made of light. [...] But the sign (ma'nā) was always one: it was Salmān, threshold of the Prophet, who manifested himself together with Muhammad in each of his epiphanies among the Arabs and the Persians. Other thresholds had manifested themselves together with Muhammad in various shapes, forming [the hierarchy] of the Thresholds, the Orphans (aytām), the Nobles (nuğab $\left.\vec{a}^{\prime}\right)$, the Leaders (nuqaba $\vec{a}^{\prime}$ ), the Elects (muștafiyyin), the Competents (muhtașisin), the Examiners (mumtahininn), and the Believers (mu'minin $).{ }^{42}$ The sign of the Threshold is Salmān, and he is the messenger of Muhammad, and is connected to him, while Muhammad is the Lord $(a l-r a b b)$. The sign of the Orphan is Miqdād. He is so-called because he is close to the Threshold, but stands in solitude because he is not joined to the first two (li-qurbihi min al-bāb wa-tafarrudihi bi-l-ittișāl minhumāa). The Orphans are two, the minor and the major: the greater is Miqdād, the lesser is Abū Darr.

As described in the heresiography, the initiatory approach to the Imam's esoteric knowledge proceeds according to a paradigm of epistemic access based on the symbolism of the adoption and assumption of the Imam's legacy of knowledge by a figure totally extraneous to the Prophet's offspring. Emphasis is placed on figures that exalt this extraneousness through the paradigmatic condition of the stranger or the Orphan, symbolized by archetypal figures of the conversion to Islam such as Abū Darr, al-Miqdād, and Salmān, who were among the first companions of 'Alī: all three are characterized by a condition of extraneousness and liminality. An intense elaboration at both a hagiographic and at a symbolic and mythological level had developed around them. ${ }^{43}$ Shiite heterodoxy makes them symbolic steps of the initiatory hierarchy towards the Imam's knowledge. Al-Nawbahtī and al-Qummī, relying on the same source, denounce these

41 al-Qummī, Maqālāt, 56-7.

42 Cf. $U K, 92$, ff. 73-4; KHA, 45-8; KȘ, 325-7.

43 On Salmān, see the classic L. Massignon, "Salmān Pāk et les prémices spirituelles de l'Islam iranien", in Opera Minora (Beirut: Dar al-Maaref, 1963), I, 443-83, and J. Horovitz, "Salmān al-Fārisi", Der Islam 12, 1922, 178-83; A.J. Cameron, Abū Dharr al-Ghifārì: an Examination of His Image in the Hagiography of Islam (London: Royal Asiatic Society Books, 1973); G.H.A. Juynboll, "al-Miḳdād b. 'Amr”, EI2. According to Imamite Shiism, the three characters have the status of apostles (hawāriyyūn): al-Kašš̄i, Ihtiyār ma' rifat al-riğāl, ed. 'A.M. al-Ḥa'irī (Bombay: al-Mațba a al-Muștafawiyya, $1317 \mathrm{AH}), 4-18$. 
doctrines, based on a deviant exegesis of Q. 89: 15-6, and replied with what they considered to be the correct interpretation of Q. 89: 17-9:44

So they interpret God's word: "When his Lord tries him through honour and blessings, he says, 'My Lord has honoured me', but when He tries him through the restriction of his provision, he says, 'My Lord has humiliated me'. Yet, it is the very word of God that denies them, and replies to them, showing the evidence of the error in which they incur: "No indeed! You [people] do not honour orphans", - that is the Prophet - "you do not urge one another to feed the poor"- that is the legitimate Imam (al-imām al-waș $\bar{\imath}$ - "you consume inheritance greedily".

All of this is relevant to the Ğābirean problem, because exalting the role of the Orphan is the focus of the initiatory (and political) ideology that emerges from the treatises included in the last collection of the corpus, the Five Hundred Books. If the corpus was complete, as Kraus proposed, by the fourth/tenth century, the Ğābirean treatise entitled Kitāa al-Māğid could be one of the first attestations (if not the earliest) of a principle of the $\operatorname{Sin}$ (actually unknown to heresiographers) alongside the principles of the 'Ayn and Mim, polemically addressed to the only other contemporary claim founded on the triad 'Ayn-Mìm-Sin and on the charismatic role of the $b \bar{a} b$, originating from al-Husayn b. Hamdān al-Hasīibī (d. 346/957) and his circle between the lesser and the greater Occultation. ${ }^{45}$

Some treatises of the last two collections of the Ğābirean corpus thus provide important clues to establishing the religious (and political) position of the Gaabirean community within the context of the conflicts and tensions that arose in the aftermath of the proclamation of the twelfth Imam's concealment. In this context, several fronts within the Shiite community contended with each other for the intellectual, religious and political legacy of the Imamate. These treatises give rise to a self-referential vision of the messianic role of the alchemist/scientist. On a theoretical basis, the Ğābirean community - identifying itself in the figure of the Orphan, the supreme epistemic access to the Imam's knowledge - declared itself to be the legitimate heir of the contested legacy. In cultural terms, the community participated in the main philosophical debates that overcame the boundary between the Sunnis and the Shiites: the problem of the law (šarí $a$ vs. nomos) and the problem of how to acquire knowledge which the Ğābireans imagined could be reproduced. In operative terms, the

44 al-Nawbahtī, Firaq al-šs̆ $a$, pp. 33-4; al-Qummī, Maqālāt, 46. On the common source: W. Madelung, "Bemerkungen zur imamitischen Firaq-Literatur", Der Islam 43, 1967, $37-52$.

45 A similar "trinitary" doctrine concerning Muhammad, 'Alī, and Salmān, where a presence of the principle of the $\operatorname{Sin}$ stands out beside those of the Mim and the 'Ayn, is attested only in another $\dot{g} u l a \bar{t}$ expression such as that of al-Hasībì: see. M. Moosa, Extremist Shiites. The Ghulat Sects (New York: Syracuse University Press, 1988), 342-51; M.M. Bar Asher and A. Kofsky, "An early Nușayrī theological dialogue on the relation between the Ma'nā and the Ism", in Le Muséon, 108, 1995, 169-80; Bar Asher and Kofsky, The Nușayrī-'Alawì Religion. An Enquiry into its Theology and Liturgy, 7-42; Friedman, The Nusayrī-'Alawīs, 73-80. 
Ğābirean Utopia came to conceive of the creation of a creature capable of reproducing the supreme quality of the Imam: a legislative disposition (nāmūsi al-țibā').

\section{The political-philosophical issue of knowledge}

The brain and its faculties was one of the main issues debated in the ArabIslamic intellectual scene of the fourth/tenth century. ${ }^{46}$ In that same period, philosophical thought was concerned with another significant problem: understanding the divine Law according to the Platonic sense of the nomos. Knowledge and its acquisition lie at the very heart of Shiite epistemology: knowledge of the Imam was in itself a theory of cognition. The late antique cultural legacy led in ambivalent terms to a physical and religious approach to the debates on the modalities of the intellect. The long passage in the $U K$ in which the Imam Muhammad al-Bāqir describes the hierarchy of the senses in correspondence to an initiatory hierarchy formed by certain characters depending upon their different approach to the Imam is an aspect of these investigations. ${ }^{47}$

In the $K S ⿱ S$ - an excellent allegory of knowledge - the Imam Ğa far al-Șādiq describes a theory of perception according to which the senses form an apparatus that acts as a filter of the intellect ( $a q l$ ), which is the substance giving the senses the right order (al-ğawhar al-mudabbir). The sirät, namely the path to knowledge, is accessed through the senses and the intellect. Cognitive experience is expressed through language, which translates the processes of the intellect into action. The senses, driven by the will, are the interpreters and translators of the ordering substance. Language is brought back to the level of $z \bar{a} h i r$ (the realm of appearance) while the intellect belongs to the level of battin (the realm of esoteric knowledge). Those aware of the logical processes underpinning the modalities of knowledge acquire an increase in perception that consolidates self-consciousness ( $z \bar{a} d a \quad f i$ mawğùdihi): alongside the theory of perception, a theory of happiness and health is thus outlined. ${ }^{48}$

Ğābir is aligned with this configuration of knowledge, which in religious terms originates from the Imam and returns to the Imam. Nonetheless, the Ğābireans widen the boundaries of the investigation, conceiving of a "scientific" answer to a religious-philosophical dilemma - indeed, one that is consequential, albeit disruptive, to the progression of the desires that alchemy allows its pupils (a consequence of increased self-consciousness?): the artificial generation of human beings. ${ }^{49}$ This problem is systematically addressed in the Kitāb $a l$-Tağm $\bar{\imath}$ and in the Kitāb al-Tașrîf..${ }^{50}$ However, artificial generation seems to

46 See below, n. 51.

$47 U K, 44$, ff. 300-1.

$48 K S, 337-41$.

49 On the artificial generation of living beings in medieval Islamic occult sciences cf. L. Saif, "The cows and the bees: Arabic sources and parallels for pseudo-Plato's Liber Vaccae (Kitāb al-Nawāmīs)", Journal of the Warburg and Courtauld Institutes, 79, 2016, $1-47$.

50 The two treatises belong to the third collection, the Kutub al-mawāzin, but the issue is already somewhat anticipated with the creation of minerals in Kitāb al-Sab'inn (in MR, 461-2), included in the earlier collection of the Seventy Books. On artificial generation 
be just one outcome that leads to further different perspectives: in the Kitāb al-Tağm $\bar{\imath}^{\prime}$, the assembling of a human body is linked to the problem of knowledge, its acquisition, and the physiological devices that determine it. Gâaireans share the classical Galenic tripartite brain theory, and pay special attention to which of the three parts is the most suited to generate knowledge acquisition processes: the part in which imagination (hay $\bar{a} l$ ) lies; the part where thought ( fikr) resides; or the part devoted to memory $(\underline{d i k r}) .{ }^{51}$ They are especially interested in learning how knowledge manifests through cognitive competence and language (wuqū' al-ilm lahu wa-l-nuț). ${ }^{52}$ However, behind the aim of creating brain faculties lies a political project. The Ğābireans sought to give life to an intelligent creature "endowed with life (hayy), penetration ( $h \bar{a} d d)$, imagination

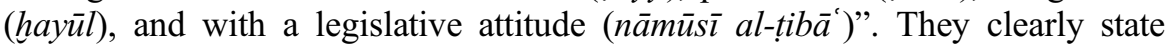
that they were able to generate law-bearing beings (tawlīd aṣhāb al-nawāmīs). ${ }^{53}$

What sources do the Ğābireans refer to explicitly? Pseudepigraphic texts, such as a Kitāb al-Tawlìd attributed to Porphyry, or a pseudo-Platonic Kitāb al-Nawāmīs. ${ }^{54}$ Despite the apparent modernity of the project, the Ğābirean library contains texts belonging to a Hermetic - or better pseudo-Hermetic ${ }^{55}$ tradition closely linked to the physika dynameis literature and theurgical procedures of late antiquity, with which the body of knowledge informing the Kitāb $a l-T a g m{ }^{\prime}$ is still imbued. But a shift in the operative axis regarding the legislative nature of the creature also reveals a commitment, and the Ğābireans' participation in issues that engaged the fourth/tenth-century political philosophy, in search of a conciliation (as in the case of al-Fārābī) between the nomos of the Greek philosophical tradition and the $\check{s}^{-} \bar{r}^{-} a$ contained in the Islamic revelation. In this period, Islamic political philosophy inspired by Plato ${ }^{56}$ had in fact led

and the relationship between Greek and Ğābirean alchemy cf. Kraus, "Contribution II", $102-34$

51 Tenth-century Islamic medical and philosophical thought is concerned with the theory of the tripartite brain: cf. the Ğābirean view in Kitāb al-Tașrīf, in MR, 371-4, Kitāb

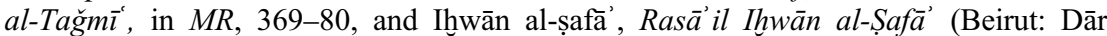
Șādir, 1957), III, 376, al-Fārābī, Mabādì àrā' ahl al-madīna al-fādila (al-Fārāầ on the Perfect State), a revised text with introduction, translation and commentary by Richard Walzer (Oxford: Clarendon Press, 1985), 178-85, 244-7. As regards the Greek medical tradition in which that issue was rooted see Kraus, "Contribution II", 116-9; L. Capezzone, "Knowing, remembering, imagining: approaches to the topic of memory in medieval Islamic culture", in Y. Tzvi Langermann and R.G. Morrison (eds), Texts in Transit in the Medieval Mediterranean (Philadelphia: Penn State University Press, 2016), 85-100. Cf. al-Fārābī, Risāla fìl-'aql, ed. M. Bouyges (Beirut: Imprimerie Catholique, 1938), 100.

52 Kitāb al-Tağmī', in $M R, 370-1$.

53 Kitāb al-Tağm $\bar{\imath}^{\prime}$, in $M R, 343$. As is usual, the Ğābireans describe the experiment as if it had already been carried out and had succeeded.

54 Cf. D. Pingree, "Plato's hermetic Book of the Cow", in R. Prini (ed.), Il Neoplatonismo nel Rinascimento (Rome: Istituto dell'Enciclopedia Italiana, 1993), 133-45 (133-4); R. Prini, "From Hermes to Jābir and the Book of the Cow", in Magic and the Classical Tradition, ed. C. Burnett and W.F. Ryan (London: Warburg Institute, 2016), 19-28.

55 Cf. van Bladel, The Arabic Hermes, 238; Kraus, "Contribution I", 212.

56 On the complex question of al-Fārābī's reading of Plato, see. G. Tamer, Islamische Philosophie und die Krise der Moderne. Das Verhältnis von Leo Strauss zu Alfarabi, 
falsafa to investigate, on the one hand, the correlation between the concept of law and the philosophical status of those who promulgate laws and, on the other, the recognition in Islamic terms of the political significance of the divine revelation. ${ }^{57}$

We know from Ibn al-Nadīm that the last collection, the Five Hundred Books, had been planned in view of a refutation against the philosophers (naqdan 'alä'l-falāsifa). ${ }^{58}$ Of course, we do not know against which philosophers the controversy was targeted - the ancients or the moderns. ${ }^{59}$ However, the current use, also contemplated by Ğābir, which distinguishes between the term hukama $\vec{a}$ (referring to an ancient wisdom, with which alchemists were in contact), and the term falāsifa (usually applied to pure Greek philosophy, but also to the great masters of the alchemical Art) seems to denote a specific direction of the polemical intent. Moreover, the Ğäbireans share the philosophical-political framework of the debates on the relationship between politics and intellect: the laws (nawāmis) those texts refer to are explicitly related to political government (siyāsa). ${ }^{60}$

Faced with the bewilderment experienced within the Shiite community after the disappearance of the Imam, the challenging response provided by the Ğābirean community seems to be aimed at overcoming the historical person of the Imam - not denying him, but instead reacting to his absence - which made the correct application of the šari $a$ impossible to accomplish. This leans towards what we might even call science-fiction ante litteram. Nonetheless, it enhances the redemptive role of science (alchemy) and the political function (in the Platonic sense) of the elite of scientists: they can generate a creature that is not the Imam, but that reproduces the brain mechanisms, giving rise to a complex body capable of offering salvation through the law. At least so they declare, adhering to the semiotic system of the alchemical communication according to which the experiment is always described, without having been achieved.

Avicenna und Averroes (Leiden: Brill, 2001), 67-77, 207-62, 290-96 (on the Arabic tradition of a pseudo-Platonic Book of Laws).

57 R. Walzer, "al-Farabi's theory of prophecy and divination", Journal of Hellenic Studies 77, 1957, 142-8; J. Macy, "Prophecy in Alfarabi and Maimonides: the imaginative and rational faculties", in S. Pines and Y. Yovel (eds), Maimonides and Philosophy (Dordrecht: Martinus Nijhoff Publishers, 1986), 185-201.

58 Ibn al-Nadīm, Fihrist, 423.

59 In the Kitāb al-Tağmĭ , in MR, 369, Ğābireans explicitly intend "philosophers" to mean those who are concerned with artificial generation (a'nī bi'l-falāsifa aṣhāo al-takwīn $a l-h \bar{a} s \underline{s} a$ ). According to Kraus, "Contribution II", 103-34, the Ğābireans address their confutation to some representatives of Hellenistic theurgical thought. In fact, they base their theories on the authority of (pseudoepigraphic) works by authors such as Porphiry, Plato, Homer, and so on, possibly using those authorities of the past with a political aim directed, as we shall see, at some contemporary debates.

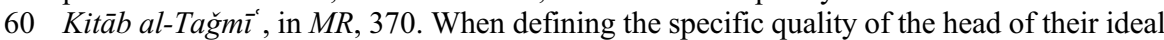
city, Ihwān al-Șafầ also distinguish between the figures of Imam, the bearer of šari $\bar{l}^{\prime} a$ (wāại al-šarī'a), and the bearer of nomos (wādil al-nāmūs): Rasā'il, IV, 130-48. Cf. I.R. Netton, "Brotherhood versus Imāmate: Ikhwān al-Ṣafă' and the Ismā îlis", Jerusalem Studies in Arabic and Islam, 2, 1980, 253-62. 


\section{The political perspective of the Ğābirean community}

Paul Kraus deemed the Kitāb al-Hamsinn to be one of the Ğäbirean texts that best illustrates the alchemical community's affiliation to Ismailism. ${ }^{61}$ Here the Ğâbirean writers offer their vision of the history of the Imamate. There are no particularly discordant positions with respect to the current views: the controversial cases of Muhammad b al-Hanafiyya and the succession of Ğa far al-Ṣādiq are examined. According to the Ğābireans, who speak here in the first person $(f a-n a q \bar{u} l u)$, with regard to the appointment of Ismā' $\bar{l}$ l followed by a rethinking in favour of Mūsā al-Kāzim, the sixth Imam would have acted according to his cognitive faculties. ${ }^{62}$ Gaābir does not seem to deny the legitimacy of the Imams after al-Kāzim, although he admits that some Imams were more important than others. The implicit position of the Ğābirean community stands firm in acknowledging the absolute charisma of Ğa'far al-Ṣādiq, and seems to accept the legitimacy of al-Kāzim's Imamate as a consequence of that charisma. A passage from the treatise reports the opinion of a group ( $t \vec{a}$ ifa) according to whom, if the order of the Imamate kept stable (mustaqim) by the first six Imams had been followed by a period of disorder and confusion, it would have been marked by the emergence of an Imam vicar with the status of nattiq. Instead, again according to this group, Ğa far al-Ṣādiq revealed his knowledge of a final order ( $\check{s} a d d a d a$ al-ilm wa-nazarahu) in such a way as to render useless the advent of a vicar to fulfil the role of nătiq. ${ }^{63}$ Ğäbir emphasizes the unlikeliness of such an assertion without adding anything else. Given that, for him, the Imamate is primarily a question of 'ilm, his objection can be interpreted as an act of exclusive dependence on the sixth Imam. ${ }^{64}$ In the following passage, Ğābir suggests that the person ( $\check{s} a h s s)$ who acquires total knowledge and is able to unify both the eloquent and silent dimension ( $\breve{g} \bar{a} m i i^{\prime}$ al-nuṭq wa-l-samt) is represented by the same Ğäbirean corpus. The internal consistency of the corpus leads us to read this statement within the framework of the Ğäbirian mimesis, which sees the Imam saying to his pupil "Kneel in front of me, o Ğābir, because in truth you shall kneel to yourself". Or when Ğābir, now a teacher, tells one of his disciples: "If you know the reasons of the order I have given to my books, you will be Ğābir". 65 The

61 Kitāb al-Hamsīn, in MR, 489-500. Here I refer to chapters 36-38 of the treatise. Kraus, "Les dignitaires de la hiérarchie religieuse", compared the Ğābirean terminology to that of the $U K$, then considered to be an Ismailite text. Now we know, also thanks to texts such as $K H A$ and $K S$, that such terminology was common to all the movements of Shiite $\dot{g} u l u w w$.

62 Kitāb al-Hamsinn, in $M R$, 499. On the views on the Imamate presented in this treatise, cf. Lory, Alchimie et mystique, 84-102.

63 Kitāb al-Hamsìn, in MR, 493-4.

64 Lory, Alchimie et mystique, 102-4, comes to similar conclusions, but exclusively framed from an eschatological perspective. My opinion is that this treatise, like the others studied here, is religiously and politically connected to the controversial Shiite climate during the lesser and the greater gayba.

65 Respectively: Kitāb Ihrāă mā fì l-quwwa ilā l-fíl, in MR, 79; Kitāb al-Māğid, in MR, 116. Cf. P. Lory, "Ésotérisme shi' ite et alchimie. Quelques remarques sur la doctrine 
Ğābirean political view leads to an apocalyptic dimension in Kitāb al-Bayān: ${ }^{66}$

This person, o brother, will appear only in a moment that will make inevitable profound mutations (intiqalät), when the sciences will be neglected, the religions will be corrupted, the disorder will be unchallenged. It will be then that a total refoundation will manifest itself: then, the first renewal that [that person] will bring will be the composition of books on the sciences, and the demonstration of the irrefutable proofs they contain. Then, that person will raise his sword, and with the sword will reform the souls of those who cannot get enhanced, and need to be induced in a cycle of purification (takris $),{ }^{67}$ since they are incapable of purifying themselves with the sciences.

We might question whether that person, transposed here in an apocalyptic dimension, is the same person who in the Kitäb al-Hamsin embodied the attributes of explicitation and silence, evidently destined to establish the nomos/ nāmūs.

The Kitāb al-Hamsin is a text fundamental to understanding the political-religious views of the Ğābirean community. The progression of the names designating the degrees of the initiatory hierarchy (55), as indicated in the list that opens the treatise, does not correspond to the exact position they occupy in the hierarchy. This is specified only later, when the author comments on the attributes of each degree. In the first list the Orphan (yatim) is ranked twentieth, but in the comment he appears according to the real succession thus illustrated: ${ }^{68}$

Some claim that each of these people holds the knowledge of the Imam; this would allow them to become Imams. The most acute discernment is proper to those who possess reason: that is their definition of Imam, for which [the Imam] is the one who in addition to possessing a complete knowledge also knows how to put it into practice. However, other people [of the hierarchy] do not act [by virtue of that knowledge] nor can they impose it. The Veil is composed of two persons: one is good, adorns himself with that knowledge and with the company of men, and if questioned he transmits [his knowledge] showing himself gently; the other is evil, hides [knowledge] and is arrogant. The Orphan is educated by the Imam (tarbiyat al-imām), ${ }^{69}$ and is always bound to him. It is veiled, and only

de l'initiation dans le Corpus Jābirien", in M.M. Amir-Moezzi (ed.), L'ésoterisme shi ite. Ses racines, ses prolongements (Turnhout: Brepols, 2016), 411-22.

66 Kitāb al-Bayān, in $A W, 12$. See the translation by P. Kraus, "Dschābir ibn Hajjān und die Ismā īilija", 3. Jahresbericht, Forschungs-Institut für Geschichte der Naturwissenschaften, 1930, 23-42; the one by Marquet, L'alchimie des philosophes, 97-8, and the one by Lory, Alchimie et mystique, 99-100.

67 The three scholars mentioned above translate takrīr as "reincarnation".

68 Kitāb al-Hamsìn, in MR, 490. See the French translation by Kraus, "Les dignitaires de la hiérarchie religieuse", 88-90, which differs from mine in some passages.

69 Kraus, "Les dignitaires de la hiérarchie religieuse", 88: "l’Adopté de l'imām". 
the Imam can see him. The Threshold $(b \bar{a} b)$ is the operator of the great Work, which can only be explained by the words [of the Prophet]: "I am the city of knowledge and 'Alī is the key". It is good to clarify how every Prophet, Imam, Orphan and Threshold can be defined as such, and then to proceed with other people. [...] Not all Imams have to deal with an Orphan, even if there have been Imams in connection with an Orphan: that is not the image (șüra) of Hasan, Husayn and Muhammad b. al-Hanafiyya in relation to 'Alī, who was instead in that particular relationship with the Prophet, while instead 'Alī was an Orphan. Likewise, there was no Threshold between them, whereas 'Alī was a Threshold. These two figures [the Orphan and the Threshold] represent two distinct virtues ( fadlāan), even if their personifications (ašhāṣ) coincide. The subsequent Imams [after 'Alī] learned from their Thresholds. This is why Husayn was preferred by some to Hasan, because the latter learned from his father, while the first learned as much from his father as from Hasan. And although it was said that Hasan had learned from the Prophet, from 'Alī, and from Salmān, yet Husayn had learned from all three, and furthermore from his brother. [...] As to the difference between the Prophet and the Imam, the first speaks, the second is silent. The Prophet commands, and the Veil is commanded, the Imam is commanded but knows what has been commanded, while the Veil does not know the command received as a whole. The Prophet acts, governs and commands, while the Orphan does not act, does not govern and does not command, the Imam is silent and speaks, while the Orphan does not keep silent and does not speak, and does not know the command received as a whole. The Veil is commanded, while the Orphan is not. The Prophet is

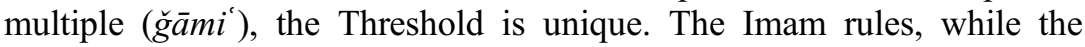
Threshold is a guide. The Threshold knows, the Veil does not know. The Threshold is joined (muttasil), but the Orphan is alone (munfașil). The Threshold is fixed, the Orphan is in movement.

Deciphering the very meaning of the attributes with which the mutual relationship between the first four figures of the hierarchy are defined is not an easy task. One can, however, grasp the historicity of such a vision by comparing it with the heresiographical record: "the Threshold is joined, but the Orphan is alone", writes Gābir; "He is called Orphan because he is close to the Threshold, but stands in solitude, since he is not joined [to the Threshold and the Prophet]", writes al-Qummī, recognizing in this image one of the muhammisa tenets. ${ }^{70}$ However, there are precise indications on the paradigmatic functions of 'Alī, who here seems to indicate that both the figures of the Orphan and the Threshold converge into the same person. The Ğābirean formulation of the priority of the principle of the 'Ayn focuses on this point.

In my opinion, this text should be read coherently with the refutative aims underpinning the entire collection of the Five Hundred Books (according to Ibn al-Nadīm). This can also be understood by looking at the opinions reported 
at the beginning on the nature of the Imam's knowledge. In particular, the Kitāb al-Hamsin should be placed in parallel to the Kitāb al-Māgrid, entirely dedicated, as we have seen, to formalizing the three principles 'Ayn - Mìm - Sin , and to prioritizing the 'Ayn over the other two on the basis of the numerical value of the letters that make up the names of the three paradigm characters.

The interpretations of this treatise converge on a fundamental point, which I too endorse: māgrid is the symbolic representation of the yatīm, of the Orphan reaching its highest degree in the hierarchy of knowledge not by virtue of a genealogical link with the Imam and the Prophet's family, but due to the absolute intellectual dependence that binds him to the Imam. This would explain the view of $m \bar{a} \bar{g} i d$ as the archetype of those who aspire to become Ğābir ${ }^{71}$ - or to cover the political role reserved for the Imam. ${ }^{72}$ The demonstration of the priority of the 'Ayn over the $\operatorname{Sin}$ through the relationship between the alphabet and numerology seems to be an even more sophisticated, cryptic version of the theory described in the Kitāb al-Hamsinn: 'Alī, the prototype of each Imam, also includes in himself the Threshold and Orphan paradigms. The absolute dependence of the Orphan on the Imam creates a relationship of exclusive privilege according to which the Orphan is implicitly superior to the Threshold. Such superiority of the yatìm over the Bāb is demonstrated by describing the close analogy between these two figures and those of the 'Ayn and the Sin: being a direct emanation of the principle of the 'Ayn, the Orphan is the immediate holder of the Imam's knowledge. This privilege is recalled in a minor treatise of the same collection, the Kitāb al-Halìl, where the authors implicitly refer to the passages on the Orphan in the Kitāb al-Hamsin, and thus write: "We have already spoken about the attributes of the Orphan, saying that he was instructed by the Imam. He is his delegate $\left(n \bar{a}^{\prime} i b\right)$, and later (ba'd: after his concealment?) he takes his place (qāma maqāmahu) as if he were his son." 73

As we have seen, an affirmation stands out with all its disturbing weight among the functions the Ğābireans assign to the top of the hierarchy: "The Threshold is the operator of the great Work". If everything converges towards a parallel between the two ranks of the Threshold and the Orphan - as the final statement of the passage quoted here shows - which are distinct in function but unified in a single person, is it perhaps possible to perceive between the lines a declaration directed against someone who claims, in turn and at that time, the role of $b \bar{a} b$ for himself? If the Kitāb al-Hamsin implicitly refers to the refutation of the $\operatorname{Sin}$ priority contained in the Kitāb al-Māğid, is it perhaps possible to identify the target of the Ğābirean discussion as someone who, at that time, in the Shiite esoteric hierarchy of the after- $\dot{g} a y b a$, claimed the role of $b \bar{a} b$ by exalting the paradigm of the $\operatorname{Sin}$ ? The confutative aim of the last Ğābirean collection was likely directed against someone perfectly able to understand the alchemical perspective from which the Ğābireans launched its claim to primacy.

71 Marquet, L'alchimie des philosophes, 104-10; Lory, Alchimie et mystique, 83-94.

72 However, the suggestion made by Lory, Alchimie et mystique, pp. 82-3, is of great value: that the Gâbirean community, although identified in the rank of the Orphan, does not assign it any function or public engagement in the Shiite reformed establishment.

73 Kitāb al-Halīl, in M. 'A. Abū Riḍā, "Risālatān falsafìyatān li-Ğābir ibn Haiyān", Zeitschrift für Geschichte der arabisch-islamischen Wissenschaften, 2, 1985, 75-84: 81. 


\section{Contextualizing the last Ğābirean treatises}

The $\operatorname{Sin}$ paradigm, to which the supremacy of the figure of the $b \bar{a} b$ corresponds, could have been another answer to overcoming the crisis following the disappearance of the twelfth Imam. During the period of minor concealment (260/874-329/941), when relations between the Imam and the Shiite community were managed by the four sufar $\vec{a}^{\prime}$, a harsh confrontation divided the orientations of Shiism..$^{74}$ At the top of the wikala governing the Shiite community, the elitist tendencies related to muhammisa stood against a front whose goal was to stress the theological-juridical nature of the Imam's knowledge, and was possibly more willing to provide answers to the doubts raised by the masses. ${ }^{75}$ In this period, marked by Ibn al-Furāt's powerful pro-Shiite visirate, a tendency emerged, which Abū Ğa far al-Ṭūsī defined as bābawiyya. The challenge against the government of the sufara $\bar{a}^{\prime}$ came from the bureaucratic apparatus at the highest level of the Shiite community. ${ }^{76}$ Among the most important supporters of this elitist current was a prominent Shiite theologian, Muhammad b. 'Alī al-Šalmag̉ānī (d. 322/934), who claimed the right to be the privileged representative ( $b \bar{a} b)$ of the concealed Imam. After having been protected by some powerful Shiite families

74 E. Kohlberg, "From Imāmiyya to Ithnā 'Ashariyya", BSOAS 39, 1976, 521-34; V. Klemm, "The four sufarä of the Twelfth Imām. On the formative period of the Twelver Shī'a", in E. Kohlberg (ed.), Shi ism (The Formation of the Classical Islamic World 33, Aldershot: Ashgate, 2003), 135-52; J.M. Hussain, "The role of the Imamite Wikāla with special reference to the First Safir", Hamdard Islamicus 5, 1982, 25-52. J.M. Hussain, The Occultation of the Twelfth Imam: A Historical Background (London: Muhammadi Trust of Great Britain, 1982); Amir-Moezzi, Le guide divin, 245-64; S.A. Arjomand, "The crisis of the Imāmate and the institution of occultation in Twelver Shi'ism: a sociohistorical perspective", International Journal of Middle East Studies 28, 1996, 491-515; S.A. Arjomand, "Imam Absconditus and the beginnings of a theology of occultation: Imami Shi ism circa 280-90 A.H./900 A.D.", Journal of the American Oriental Society, 117, 1997, 1-12; H.A. Abdulsater, "Dynamics of absence. Twelver Shi'ism during the Minor Occultation", Zeitschrift der Deutschen Morgenländischen Gesellschaft 161/2, 2011, 305-34.

75 According to M.A. Amir-Moezzi, The Spirituality of Shi i Islam. Beliefs and Practices (London and New York: I.B. Tauris, 2016), 225: "the 'theological-legal-rational' movement, which continues to this day, began to dominate, thus marginalizing the original 'esoteric non rational' current". For a discussion on labelling and categorizing the two fronts see Abdulsater, "Dynamics", 321 and n. 106.

76 Al-Kaššì, Ihtiyār $r, 321-2$ ( fì l-giulāt fì waqt 'Alī b. Muhammad), seems to recognize the existence of this current during the Imamate of 'Alī al-Hādī, and reports the case of 'Alī b. Hasaka and his disciple al-Qāsim b. Yaqțin, both supporters of the divinity of the Imam, and their claim to the role of $b \bar{a} b$. This claim emerged from within the wikäla apparatus (on which see Hussain, The Occultation, 79-98, Modarressi, Crisis and Consolidation, 12-16). According to this source, the Imam 'Alī al-Hādī condemned this form of extremism supported by al-Ḥasan b. Muḥammad b. Bābā al-Qummī (mentioned in the isnād of KȘ, 381, see L. Capezzone, "Una nuova fonte per lo studio dell'eterodossia islamica: il Kitāb al-șirāt attribuito a Mufaḍdal b. "Umar al-Ğu' fî", Rivista degli Studi Orientali, 67, 1993, 265-71: 270), companion of the tenth and the eleventh Imams, and disciple of Muhammad b. Nuṣayr al-Numayrī (d. 270/883-4). The latter self-proclaimed himself safì and $b \bar{a} b$ of the concealed Imam (al-Kašší, Ihtiyār, 323, Hussain, The Occultation, 103-5; Halm, "Das 'Buch der Schatten' II", 72-9; Friedman, The Nușayrī' Alawīs, 6-16; Abdulsater, "Dynamics", 312-3). 
of Baghdad, ${ }^{77}$ he was forced into exile in Ma latāyāa (northern Iraq), and was then arrested and put to death with some of his followers. ${ }^{78}$

Ibn al-Nadīm includes al-Šalmağānī among the names of the philosophers who dealt with the speculative aspects of alchemy (al-falāsifa alladina takallamu fi l$_{\text {-șan }}$ a), ${ }^{79}$ emphasizing its prominent place in alchemical practice. This source is the only one to mention the four titles of his alchemical works, which include a comment (̌̌arḥ) on Ğābir b. Hayyan's Kitāb al-Rahmma. ${ }^{80} \mathrm{We}$ know that a conceptual topos denoting the strong doctrinal dualism of al-Šalmagān $\overline{1}$ - who conceived of reality as a succession of pairs of opposites is represented by the idea of didd, the demonic and adversative principle which informs his emanationist metaphysics. The term also occurs in the lexicon of the $K S$, which currently uses it in a perspective that likely recalls the doctrine of the opposites as the sources attribute it to al-Šalmagānī. ${ }^{81}$ In the Seventy Books collection, Ğābir uses it to indicate negative physical qualities inherent in the elementary structure of substances. ${ }^{82}$

Dedicating a comment to the earliest text of the Gābirean corpus could represent a very precise choice connected to the history and evolution of that school. The same inclination (shared by many, as Ibn al-Nadìm wrote) to deem the Kitāb al-Rahmma the only treatise actually authored by Ğābir b. Hayyān, pupil of Ğa far al-Ṣādiq, may underlie such a choice. If this were the case, this choice could have been dictated by less philological than ideological reasons. Writing a commentary on the first text of a corpus that had undergone an evident evolution over time, with such important epistemological developments and so profoundly marked by autonomy of thought within the entire Shiite episteme, could mean questioning such an evolution and development: in other words, it could mean a return to the origins of the school.

Throughout the last treaties - the Kitāb al-Hamsinn and the Kitāb al-Māğid in particular - the Ğäbirean community developed a system of relations among the Shiite hierarchical figures which strongly regulated the function of the $B \bar{a} b$ and of the Yatìm - a figure tasked with implementing the reform announced by the Kitāb al-Bayān, and with which the Ğäbirean elite identifies. ${ }^{83}$ The hierarchy as imagined by al-Šalmaḡān̄ may have had to adhere to an immobile structure

77 L. Massignon, "Recherches sur les Shi ites extrémistes à Bagdad à la fin du troisième siècle de 1'hègire", Opera Minora, I, 523-36; Newman, Formative Period, 23-6.

78 al-Ṭūsī, Kitāb al-Gayba (ed.), Mūsawī, Qumm, 1408 AH, 214-28. Hussain, The Occultation, 126-30; Newman, The Formative Period, 23-5; Abdulsater, "Dynamics", $317-30$

79 Ibn al-Nadīm, Fihrist, 419, mentioning him as al- 'Azāqirī. Cf. the same source, at 423, where the Five Hundred Books collection is depicted as a refutation of the philosophers (naqd'alā l-falāsifa).

80 Ibn al-Nadīm, Fihrist, 425, under the entry Ibn Abī l- 'Azāqir.

81 Fragmentary elements for a tentative reconstruction of al-Šalmaḡānīs doctrines, as reported by sources such as Yāqūt's Iršăd al-arīb or al-Ṭūsì's Kitāb al-Ġayba, have been gathered by Charles Pellat, "Muhammad ibn 'Alī al-Shalmaghānı̄", $E I^{2}$. Cf. the hostile portrait given by Louis Massignon, La passion d'al-Hallaj martyr mystique de l'islam, Paris, Gallimard, 1975, sub index.

82 E.g. in Kitāb al-Hudā, in L'élaboration de l'élixir suprème. Quatorze traités de Jābir ibn Hayyān sur le Grand Euvre alchimique, ed. Pierre Lory, 5.

83 See above, n. 66. 
whose apex was the $B \bar{a} b$. The refutation of the $\operatorname{Sin}$ priority formulated in the enigmatic Kitāb al-Māğid - highly obscure for all those outside such a semiotic code - may have been perfectly understandable to the alchemist al-Šalmagiānī.

\section{Conclusion}

The absolute secrecy under which the Ğābireans chose to operate makes it difficult, but not impossible, to locate them in their historical space. In the last treatises of the corpus - where the alchemical concern leaves more room for the political-religious attitude - this community explicitly claimed control of the political and intellectual legacy of the hidden Imam, and presented itself as the yatìm, a figure also known to other gulāt doctrinal views that marked the struggling Shiite panorama between the lesser and the greater Occultation. In this controversial climate, they disputed and came into conflict with other $\dot{g} u l u w w$ groups, resorting to a common language focused on the transfer of the Imam's charisma to a figure extraneous to the Alid family, in order to affirm the pre-eminence of their intellectual role. The Ğābirean project, which aimed to generate an artificial imam in a laboratory, was their own response, disconcerting yet consistent with their salvific view of science, to the absence of the Imam. However, the legislative function of the artificial imam would no longer have been linked to the šar $\bar{l}^{\prime} a$ (only possible with the living Imams), but to the $n \bar{a} m \bar{u} s$. Again, the Ğābireans left a trace that allows us to place them in a precise historical and cultural space: from their perspective, they actually participated in a philosophical-political debate on šar $\bar{l}^{\prime} a$ vs. nomos, specific to the fourth/tenth century, inaugurated by al-Fārābī. 